\title{
THE IMPLEMENTATION OF CONSUMER PROTECTION ACT ON COSMETIC BUSINESS AGENTS (STUDY OF COSMETIC SUPERVISION AT MAKASSAR AGENCY OF FOOD AND DRUG CONTROL)
}

\author{
Fitri Wulandari \\ Postgraduate Program,Universitas Islam Negeri Alauddin Makassar, South \\ Sulawesi, Indonesia, Jl. Sultan Alauddin No 36 Makassar, 90211 \\ E-mail: 80500216013@uin-alauddin.ac.id \\ Muh. Saleh Ridwan \\ Postgraduate Program,Universitas Islam Negeri Alauddin Makassar, South \\ Sulawesi, Indonesia, Jl. Sultan Alauddin No 36 Makassar, 90211 \\ E-mail: saleh.ridwan@uin-alauddin.ac.id

\begin{abstract}
Patimah Patimah
Postgraduate Program,Universitas Islam Negeri Alauddin Makassar, South

Sulawesi, Indonesia, Jl. Sultan Alauddin No 36 Makassar, 90211

E-mail: fatimahhalim6@gmail.com
\end{abstract}

\begin{abstract}
This study is entitled Implementation of the Consumer Protection Act on Cosmetic Business Agents (Study of Cosmetic Supervision at Makassar Agency of Food and Drug Control). This study describes how to supervise the implementation of consumer protection act on cosmetic businesses. To obtain answers to this problem, the writers use three methods of the data collection; Observations, interviews, and documentation. In field research, the writers use observation and interview instruments. Qualitative Data processing and the data analysis techniques that are used; Data reduction, the data presentation, and verification of data. The samples in this study were the Head of the Agency of Food and Drug Control, the Head of Examination Department, the Head of Enforcement Department, the Head of Testing Department, the Head of Information and Communication Department, some business agents and consumers. The results of this study indicated that the application of the consumer protection act has been carried out by cosmetic business agents in Makassar, the agents have applied all the rules relating to the production and distribution of products as well. Supervision of cosmetic businesses by Makassar Agency of Food and Drug Control both in the market and at the clinic has proceeded properly.
\end{abstract}

Keywords: Implementation of Consumer Protection; Cosmetic; Business Agents

How to Cite: Wulandari, F., Ridwan, M. S., \& Patimah, P. (2019). The Implementation Of Consumer Protection Act On Cosmetic Business Agents (Study Of Cosmetic Supervision At Makassar Agency Of Food And Drug Control). Jurnal Ilmiah Al-Syir'ah, 17(1), 54-64.

Permalink/DOI: http://dx.doi.org/10.30984/jis.v17i1.853

Copyright (C) 2019, Jurnal Ilmiah Al-Syir'ah

The Implementation Of Consumer Protection Act On Cosmetic Business Agents (Study Of Cosmetic Supervision At Makassar Agency Of Food And Drug Control)

Fitri Wulandari, Muh. Saleh Ridwan, Patimah Patimah 


\section{INTRODUCTION}

Consumer protection issue is more intensively discussed. This problem will never run out and will always be the subject of conversation in the community. During many consumers are harmed, the problem will never be completed. Therefore, consumer protection issues need to be considered.

Consumer rights are ignored by businesses needs to be examined carefully. In the era of globalization and free trade, many emerging a wide range of goods/services that are marketed to consumers in the country, either through promotion, advertising, or offering goods directly.

If people are not careful in selecting the goods/services desired, the consumer market will be the object of business exploitation from irresponsible business agents. Consumers take for granted goods/services they consume unconsciously.

The problems faced by consumers are not just how to select the item, but it is much more complex than that concerns the awareness of all parties, employers, government and consumers about the importance of consumer protection. Employers realize that they must respect the rights of consumers, producing goods and quality of services, safe for use or consumption, following the applicable standards, with prices to match. The government is aware that laws and regulations are necessary for all sectors related to the transfer of goods and services from businesses to consumers. The government also observed the implementation of laws and legislation properly.

The objective of implementation, development, and regulation of consumer protection is planned for developing dignity and awareness of consumers, and indirectly encourages the responsibility of entrepreneurs in carrying out their business activities, consumers must realize their rights to be protected by consumer protection act to control the behavior of employers and government socially. Act No. 8 of 1999 on Consumer Protection is expected to save consumers in Indonesia.

According to Janus Sidabalok, there are four main reasons why consumers need to be protected, as follows: Protecting consumers is equal in protecting the entire nation, as in the national development objectives under the Act of 1945; Protecting consumers need to prevent consumers from the negative impact of the use of technology; Protecting consumers need to give birth to healthy humans spiritually and physically as development actors, which means also to maintain continuity of national development; Protecting consumers is necessary to ensure sources of development funding that comes from consumer society (Sidabalok, 2006).

In cases of counterfeit cosmetic products, means herein businesses have violated consumer rights, namely the right to correct information, clear and honest about the condition and guarantee of the goods and/or services. Obligations and rights are an antinomy in law, thus, the obligation of an entrepreneur can be seen as consumer rights (Shidarta, 2000). 
Most women are very interested in purchasing cosmetic products with low price and fast results. Therefore, many women who use an alternative way to buy a product even if the cosmetic products bought are not eligible and not enrolled in The Agency of Food and Drug Control. Cosmetics are easily available at affordable prices by the absence of a marketing authorization number from The Agency of Food and Drug Control, the cosmetics have no label of raw materials and the expiry date.

Because the price is cheap and can be bought easily so that the cosmetics without a marketing authorization is easily consumed by the public. The ignorance of consumers for the side effects of cosmetics containing hazardous materials can be used as a reason for them to still use them. Consumers typically do not examine a product before buying, this could be one factor why those kinds of cosmetic are still in demand by women (Umbara, 2015).

They generally purchase the cosmetics directly without considering that the products have side-effects. Consumers are required to observant and intelligent in the purchase of cosmetic products. But what happens on the field there are still many consumers who get fake cosmetics that do not comply with quality standards for businesses The Agency of Food and Drug Control cosmetics there is still a fraudulent act against the rule of Consumer Protection Act. The Agency of Food and Drug Control is as government regulation to the quality, safety, and efficacy of pharmaceutical products and food, it must be able to carry out its duty to protect the health of society in the products consumed and registered and widely distributed in the market.

Consumer protection is not only in positive law but in Islam as well. Based on consumer protection, Islam with its Syari'ah maqashid concept also provides consumers needs fulfillment. Consumer needs are met by employers, therein should include the consideration of essential things in protecting consumers, such as meeting the needs of consumers like goods and services, that require to help maintain, preserve and do not pose a threat for consumers' religion, soul, mind, offspring, and treasures (Yuniia \& Riyadi, 2018).

In the Islamic economic law, possible violations of consumer rights can occur before selling and buying transactions take place during the advertising or promotion. It can also occur when the transaction itself takes place and after the transaction. Therefore, in these stages, legal protection should be given. In Islamic jurisprudence, the truth and accuracy of the information when businesses promote their merchandise occupies a significant study. Islam does not recognize that consumers should be careful or otherwise business agents who should be careful. The principle of balance is applied In Islam. Here between the two sides both consumers and employers should be equally cautious.

Among the many rights of consumers who get the discussion in the jurisprudence, the investigator can divide into some points, such as: The right of getting the true, honest, fair, educated and protected information and services; The availability of voting rights and fair exchange rate; The right 
to getting a healthy environment and safe product; The right of getting advocacy and dispute settlement; The right of getting protection from abuse of state; The right to redress the negative effects of a product

Based on the rights above, in the Islamic jurisprudence, correctness and accuracy of the information when businesses promote their products occupies a significant study. Islam does not recognize that consumers should be careful or otherwise business agents who should be careful. The principle of balance is applied In Islam. Here between the two sides both consumers and employers should be equally cautious (Yusri, 2009).

Considering the importance of consumer protection as a part of a consumer protection supervision, the writers intend to examine the supervision of consumer protection that is the cosmetic business agents under the supervision of Makassar Agency of Food and Drug Control.

The Agency of Food and Drug Control in Makassar as a center of the control system of quality, security, and benefit of pharmaceutical and food products, the Agency of Food and Drug Control performs its function to protect public health.

The focus of this study is monitoring the implementation of consumer protection laws on businesses cosmetics, with sub-focus: The application of consumer protection legislation in the cosmetics business agents and supervision by the Agency of Food and Drug Control to the cosmetics business agents.

\section{RESEARCH METHODS}

The type of research is qualitative research on the grounds that the object under study requires accurate data in the form of descriptive data which is obtained from various sources such as informants, phenomena, documentation, or a specific event, either individually or in groups in order examining various aspects relating to the supervision of the application of consumer protection legislation on the cosmetics business agents in Makassar.This research was conducted at the Center for The Agency of Food and Drug Control, which is located on Jl. Minasa wedge Tamarunang no.2, Mariso, Makassar.

Sources of data in this study were all the data or people who provide information relating to the needs of research. There were two sources of data used, those were primary data and secondary data. Primary data is a source of data acquired or collected directly from the object of research in the field, primary data obtained from sources informants individuals or as results of interviews conducted by researchers to the informant. Sources of primary data in this study were the Head of The Agency of Food and Drug Control, the Head of Inspection Department, the Head of Enforcement Department, the Head of Testing Department, the Head of Infocom Department, two businessmen, and two speakers. The secondary data source is data obtained or collected by the person who conducted the research from sources that already exist. This data is used to support the primary 
information that has been obtained from literature, previous studies, books, and so forth. Secondary data sources in this study were office profiles, annual reports, etc. to support the primary data.

Data collection techniques were observation, interviews, and documentation: (1) Observation (Koentjoroningrat, 2009); researchers used a technique to observe the consumer understanding of the existence of consumer protection laws. (2) Interview techniques used in this study was a structured interview, the researcher used interview guides that have been arranged in a systematic and complete the data collection. Interviews in this research addressed to the Head of the Agency of Food and Drug Control, businesses, and consumers (Narbuko \& Ahmadi, 2007). The interview was intended to obtain data for research, where researchers ask a few questions and to explore further answer directed at the focus of research by taking notes or recording to be analyzed. Therefore, questions of researchers associated with the research focus have been set and composed even though the interview was conducted on an informal basis. (3) Documentation (Ahmad, 2003): The writers conducted the documentation by using a camera and recorder to conduct the evidence that the process of research was done correctly to make the accuracy of the data.

Analysis techniques used in this study referred to the concept of Miles and Huberman (Bungin, 2009), the activity in the qualitative data analysis performed interactively and continually, hence the data was already saturated. According to Miles and Huberman, there are three steps in analyzing the data, namely: (1) Reduction of data: the researchers conducted classifying all data by selecting whether the data is relevant or not. Hence, the researchers could determine the missing data to be used as efforts to improve the data analysis process. Data classification is intended that this study focused on one topic and facilitate the writers to have the conclusion. (2) Presentation of data: Presentation of data in the study referred to by the display data. Presentation of data is done after the data is reduced. In qualitative research, the presentation of the data used is narrative text. How do qualitative research data presented in the form of a brief description, chart, relations between categories, flowcharts, and so on? (3) Verification of data: Data verification is done by reviewing the data reduction and data display so that the conclusions drawn are reliable.

\section{RESULTS AND DISCUSSION}

\section{THE APPLICATION OF THE CONSUMER PROTECTION ACT ON COSMETICS BUSINESS AGENTS IN MAKASSAR}

Cosmetics that will be produced by businesses must require quality, safety, and efficacy. Before creating and distributing products of the production license must be owned by every business as the cosmetics regulation of Minister of Health, namely: cosmetics industry which will make the production of cosmetics must have a production license; and production licenses referred to in paragraph (1) shall be issued by the General Director. 
In addition to production licenses, beauty clinics conducting the manufacture of cosmetics also have to have a marketing authorization. MD clinic also has a marketing authorization from the Ministry of Health and The Agency of Food and Drug Control. The authorization held by beauty clinics is important to distribute cosmetic products that have been produced, as a sign that cosmetic products are safe and have been certified from the Agency of Food and Drug Control. Marketing authorization has also owned by ACC beauty clinic.

The marketing authorization is set out in the regulations of the Minister of Health, as follows: Every cosmetic is only released after obtaining marketing authorization from the Minister; A marketing authorization referred to in paragraph (1) in the form of a notification; and Excluding from the provisions of the notification referred to in paragraph (2) for cosmetic use for research and cosmetic samples for exhibition in limited quantities and not for sale.

At MD and AAC clinic, there are doctors who have a background in skin health and beauty specialist and has a pharmacist who is responsible for compounding and having knowledge in compounding the product according to the patient's skin condition. Both the clinic also has a laboratory for compounding cosmetic products and use materials that have passed the certification test from The Agency of Food and Drug Control, so it can be ascertained that the cosmetic products they produce are safe.

It was consistent with the results of interviews, Andi Titi as consumers who use cosmetic products from a beauty clinic stating that during the use of a cosmetic product such as a beauty clinic cream concoction was safe because there is no negative effect and doing a consultation before using the cream. The goal is to determine the type of skin and its problems and compounded by a specialist who is credible.

Nurul as consumers also expressed that the product used is considered safe. Despite the change only takes one week, it has no effect because of the supervision of medical experts .

The quality and safety of a product is the requirement to have a marketing authorization as the results of the interview to the Head of the Test Department of The Agency of Food and Drug Control, Hamka Hasan, stated that all ingredients in the compounding of cosmetics have been registered in The Agency of Food and Drug Control .

Technological advances and the development of economy and trade volume demand extra supervision of the risks that may arise from the use of certain products. This should make businesses more cautious. A business agent in producing goods/services should always remember safety products/services they offer because production activities are not only related to the profit and benefit but also deals with the enforcement of the benefit of society. 
60

Based on the discussion above, it can be seen that the cosmetics business agents in the city of Makassar have implemented the Consumer Protection Act, in addition, the business actors also have to apply all the rules relating to the production and circulation of products. Researchers considered that business in Makassar will obey the rules because of the sanctions. The penalty imposed is focused on businesses. In addition, businesses also expect a sustainable advantage to maintain consumer confidence by always guaranteeing the quality and safety of cosmetic products as the regulation of The Agency of Food and Drug Control.

\section{THE SUPERVISION OF COSMETICS BUSINESS AGENTS BY MAKASSAR THE AGENCY OF FOOD AND DRUG CONTROL}

In the use of cosmetics, consumers have to pay attention to the legality and a trading company license, and the composition of the material contained in a cosmetic product by looking at the information available on cosmetic labels, whether cosmetic products have a number of trademark registration from The Agency of Food and Drug Control, lists of dermatology test results, and cosmetics products' expire date.

The Agency of Food and Drug Control as the agency that oversees the distribution of food and drug distribution as a form of preventive legal protection that consists of:

\section{Pre-Market Supervision}

This supervision includes the field of certification and consumer information services. Supervision is carried out before the product is distributed to the market by the registration stage, the assessment on the legal completeness content of the product whether it is safe or not, and the means of production does include information that is clear and understandable, and then it is given a registration number. This supervision includes:

\section{Certification and Product Registration}

There are many violations committed by businesses, it takes the role of the government and public to carry out prevention and control to be more vigilant and careful in consuming a cosmetic product.

Makassar Agency of Food and Drug Control as the supervising institution has a role in regulating and supervising the circulation of cosmetics so that violations can be minimized. According to interviews with Abdul Rahim as the Head of The Agency of Food and Drug Control said that cosmetics as a product supervised by the Agency of Food and Drug Control, it means that cosmetics must have a marketing authorization letter before distributing in public. Why they should have a marketing authorization letter? Because there is a process of quality assessment, safety, and efficacy. If cosmetics are distributed and not permitted by the Agency of Food and Drug Control, cosmetics are considered using prohibited substances. 
It is related to Wadania Waris statement as the Head of Investigation Department that the products in the market have to go through certification, product registration, and certification of production facilities.

Marketing Authorization is an approval form for the registration of medicinal products, traditional medicines, food supplements, food, and cosmetics issued by the Republic of Indonesia The Agency of Food and Drug Control lawfully so that the product can be marketed in Indonesia.

\section{Halal Certification and Halal Labeling}

For businesses that want to enroll halal certification to LPPOM MUI, they must meet the requirements of halal certification. Companies are free to choose the methods and approaches required to implement the Halal Assurance System (HAS), as long as it can meet the criteria for HAS.

\section{Permitting the Opening of Pharmacies, Factories, and New Facilities}

Permitting the opening of pharmacies, factories, and new facilities is a permit pharmaceutical industry. The pharmaceutical industry permission is an entity that has a license from the Minister of Health to the manufacture of drugs or drug ingredients (cosmetics).

To obtain the pharmaceutical industry authorization needs principal approval. The approval is valid for three (3) years. After completing the approval, the businesses can apply for pharmaceutical industry permission. The principle approval must be approved by Master Plan Development (RIP) issued by the Agency of Food and Drug Control. The pharmaceutical industry permission should have a recommendation from the Provincial Health Office and The Agency of Food and Drug Control.

This is relevant with Erni Arnida Tjoputera statement as the Head of Information and Communication Department that everything related to licensing including the production license, the marketing authorization, factories and facilities, and infrastructure must obtain permission from The Agency of Food and Drug Control cooperation with related government agencies. The opening of new facilities still follow the same requirements as a new permit application .

\section{Serving the Information and Complaints From Consumers}

Communities also have a role in the complaint and reported to the authorities, if there are businesses that break the law, the Agency of Food and Drug Control ensure the confidentiality of the complainant, because many people are reluctant and even afraid to report illegal products they find on the market.

While the spread of information and the danger of fake cosmetics done by creating banners, posters published in the media, one of them is in Makassar The Agency of Food and Drug Control website which is a part of public warning. Public Warning provides Makassar Agency of Food and 
Drug Control activity report and information about products that contain harmful substances, so people will not use such harmful products. Erni Arnida Tjoputera further stated that in order to avoid counterfeit cosmetics on the market is a way to check whether these cosmetics have a distribution license or not from Makassar Agency of Food and Drug Control. If there is a distribution license, consumers can check the registration number on website http://www.pom.go.id/ to determine whether registration numbers are genuine or not.

\section{Education Training to Human Resources, Regency/City Government, Manufacturers, Retailers, and the Public}

Makassar Agency of Food and Drug Control also provides public education. The extension services do as much as possible within the budget issued by the government to Makassar Agency of Food and Drug Control. By the low level of public knowledge about counterfeit cosmetics and low public awareness of the dangers of counterfeit cosmetics, the education itself is meant to give knowledge to the public about the dangers of counterfeit cosmetics and do not have a marketing authorization.

\section{Post-Market Supervision}

Post-market supervision is conducted by the Agency of Food and Drug Control when the product is already on the market. However, the supervision is not limited to the distribution of products, the facilities and the manufacture of the product should also be checked. Supervision is done by sampling, which is to buy cosmetic products on the market and do a good inspection of the contents of cosmetic products by conducting laboratory tests, as well as checks on labeling if it is eligible for release. If it is not eligible to be marketed, normally Makassar Agency of Food and Drug Control takes the product from the market.

\section{Inspection of Facilities and Distribution of Products}

As a form of supervision by Makassar Agency of Food and Drug Control in overseeing the circulation of drugs and food products is by conducting routine surveillance at the facility where the product manufacture and distribution of cosmetic products on the market.

Monitoring carried out by the Agency of Food and Drug Control find some products that are illegal, do not get a production license or use prohibited ingredients to be mixed in cosmetics. There are also many cosmetics on the market that have followed the procedures and law. The illegal cosmetic procedures will exist, whether businesses that produce illegal cosmetics have the element of intent or ignorance of the ingredients used. Surely there will be mechanisms to be run.

Mechanisms referred to by the Head of Agency of Food and Drug Control is the admonition and guidance to businesses trading in cosmetic products that are not fit for circulation, Makassar Agency of Food and Drug Control will conduct law enforcement. The enforcement can be an 
administrative sanction or criminal sanctions. The administrative sanction is intended for the means of production, distribution and beauty clinic who commits a summary offense. While criminal sanctions are intended for businesses that cannot be reprimanded or fostered by a serious violation.

Based on the discussion above, it is understandable that the supervision of the implementation of consumer laws on cosmetic business agents in Makassar both in the marketplace and in the clinic is running properly. Makassar Agency of Food and Drug Control pleasant oversight, guidance, and taking legal action against agents to prevent and minimize the circulation of fake cosmetics as a form of consumer protection law enforcement.

\section{CONCLUSION}

From the previous description, it can be concluded that: The application of consumer protection laws on cosmetics businesses in Makassar has been held with full responsibility, in addition to the business agents also have to apply all the rules relating to the production and circulation of products. Employers expect a sustainable advantage to maintain consumer confidence by always guaranteeing the quality and safety of cosmetic products relating to the regulation of the Agency of Food and Drug Control; Monitoring carried out by Makassar Agency of Food and Drug Control on cosmetic business agents both in the marketplace and in the clinic is running properly. Makassar Agency of Food and Drug Control pleasant oversight, guidance, and taking legal action against agents to prevent and minimize the circulation of fake cosmetics as a form of consumer protection law enforcement.

\section{ACKNOWLEDGMENTS}

The writer's gratitude to parents, $\mathrm{H}$. Muh. Rusli and $\mathrm{Hj}$. Sumiati who has been nurturing and guiding writers until the completion of this thesis, the writers wish that may Allah Subhana Wata'ala gives them love and forgive their sin. Amin

\section{REFERENCES}

Ahmad, A. K. (2003). Dasar-dasar Metodologi Penelitian Kualitatif. Makassar: Indobis Media Center.

Bungin, B. (2009). Analisis Data Kualitatif: Pemahaman Filosofi dan Metodologi ke Arah Penguasaan Model Aplikasi (III). Jakarta: Rajawali Press.

Koentjoroningrat, K. (2009). Metode-metode Penelitian Masyarakat. Jakarta: Gramedia.

Narbuko, C., \& Ahmadi, A. (2007). Metodologi Penelitian (VIII). Bumi Aksara: Bumi Aksara.

Shidarta, S. (2000). Hukum Perlindungan Konsumen Indonesia. Jakarta: Grasindo.

Sidabalok, J. (2006). Hukum Perlindungan Konsumen di Indonesia. Bandung: PT. Citra Aditya Bakti.

Umbara, T. R. C. (Ed.). (2015). Undang-undang No 8 Tahun 1999 tentang Perlindungan Konsumen. Jakarta: Citra Umbara. 
Jurnal Ilmiah Al-Syir'ah Vol. 17, No. 1 (2019): 54-64

Website: http://journal.iain-manado.ac.id/index.php/JIS

ISSN 2528-0368 (online) ISSN 1693-4202 (print)

64

Yuniia, F. I., \& Riyadi, A. K. (2018). Prinsip Dasar Ekonomi Islam Perspektif Maqasyid al-Syari'ah. Jakarta: Kencana.

Yusri, M. (2009). Kajian Undang-Undang Perlindungan Konsumen Dalam Perspektif Hukum Islam. Ulumuddin, 5(3). 